\title{
設計情報・意図を伴う設計プロセス支援のための統合モデル*
}

(第 2 報, ブレイクダウン設計支援)

\author{
竹内 - 博*1 妻 屋彰*2 \\ 若 松栄 史 ${ }^{* 2}$, 荒井栄 司*2

\section{Integrated Model for Computer Aided Design Process with Design Information and Intention (2nd Report, Computer Aided Break-Down Design Process)} \\ Kazuhiro TAKEUCHI*3, Akira TSUMAYA, \\ Hidefumi WAKAMATSU and Eiji ARAI \\ ${ }^{* 3}$ Fujitsu Info Software Technologies Ltd., \\ 181 Minami cho, Shizuoka shi, Shizuoka, 422-8572 Japan

\begin{abstract}
Recently, 3 D CAD systems have been rapidly improving However, the principal improvements have been focused on the geometric modeling and developing user-friendly operational improvements. It is important that $3 \mathrm{D}$ CAD systems have to improve the treatment of the design information and the intention generated in the design process. Especially to support the design process flow is very important for $3 \mathrm{D}-\mathrm{CAD}$ systems. In this paper, we discuss the important design information especially needed in the upstream design stage and propose the expanded integrated model of the geometric model and the design information. In order to support the design process, the transmission architecture of the design information and intention is proposed.
\end{abstract}

Key Words : Design Information, Design Intention, Geometric Model, CAD, Design Process

\section{1. 背景}

$\mathrm{CAD}$ システムの発展動向は, 基本的に詳細設計に フォーカスした形状処理および操作性向上に着目した 進展が多く，設計行為を支援する上で，CAD システム が設計情報・意図を扱うことは非常に重要な課題であ $ろ^{(1)(2)}$.

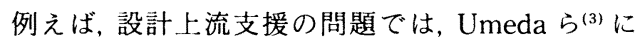
よって機能要件に基づく支援の研究や, 劉ら(4)(5) によ つて設計上流で重要な定性的な情報の扱いについての 研究が行われている，また，設計者の意図の理解の問 題では，岡田ら(6)による設計意図のモデル化や, Arai ら(7)による機能に着目した意図と幾何モデルとの関 連付けによる設計支援の研究が行われている.

これらの設計支援・設計意戝情報のモデル化研究 は、設計上流段階に焦点をあてたものであり，CAD な どを利用して詳細設計段階までどのように設計情報・ 意図を伝達し, 利用させるかといった問題については

* 原稿受付 2004 年 7 月 6 日

*1 正員，(株)富 t:通インフォソフトテクノロジ（４４228572 静岡浦南町 18 1).

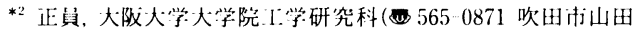
fr. 2 1).

E mail : takeuchi(a ist.fujitsu.com
まだ解決されていない.

われわれの目的は，概念設計を含む各設計工程で考 察された設計情報・意図が, 詳細設計段階でも正確に 有効に利用されるための要件・システムアーキテクチ ヤを提案することである.

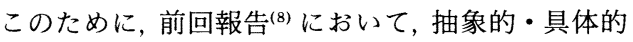
を問わず, 設計情報・設計情報間の意味合い・意図を 反映できる, 設計情報の伝達の仕方を制御可能な, 設 計情報・意図と幾何モデルの統合モデルアーキテクチ ヤを提案した。

本論文では, 前回提案したアーキテクチャを前提と して議論を進める. 本論文では, 特に設計上流段階か ら段階的に詳細化していく設計プロセスにおいて重要 な設計情報伝達に関する考察を行い, その重要な設計 情報の正確な伝達を可能にするための前回提案アーキ テクチャの拡張を提案する. また，提案するアーキテ クチャの拡張性について考察し, いくつかの有効な具 体的拡張例について提案する.

\section{2. 目的と要 件}

多くの設計においては, 始めに製品全体の概要決定 を行い, 段階的に詳細化していく設計プロセスを経 る.このような設計を本報ではブレイクダウン設計と 
呼ぶことにする.

議論に入る前に, 本論文で想定している設計上流の イメージについて述べる。ここでは, 図 1 に示すよう な, 製品全体の全体的なレイアウト概要が決まった段 階を想定している。この段階では, 幾何形状は非常に 単純であり, 線, 面, 単純なソリッドなどで構成され ている.

2 章では, 段階的に詳細化されていくブレイクダウ ン設計支援において必要となる重要な設計情報伝達に 関する要件について考察する。

冒頭にも述べたように, 設計上流段階では全体のレ イアウト概要が決定している段階であり, 線・作業面 など, 形状としては非常に簡単なものが多い.しかし ながら, それらは重要な意味を持っていることが多く, 以下に特にブレイクダウン設計で重要になる要件につ いて述べる.

\section{（1） 分解機能}

段階的詳細化のためには, 全体から各サブュニット に分解していく機能が必須である. システム的には, 各種の幾何要素が存在している状態から, 構成(サブ アセンブリー)が作成できることである.

（2）他夕イプ情報設定の必要性

非常に単純な線・平面の状態であっても，それらは サブアセンブリーや部品を表しており, サブアセンブ リーや部品としての設計情報・意図が設定可能である こと.

（3）形状状態の変更に伴う設計情報伝ぱ

非常に単純な線・平面・ソリッドの状態から詳細化 されていく.したがって, 幾何形状自身の変更に伴う 設計情報伝ぱのみならず，形状状態の変化(線を利用 したソリッド化など)に伴う設計情報の伝ぱが可能で あること。

（4）既存の幾何形状利用編集に伴う設計情報伝ぱ 既存の設計情報が設定されている幾何形状を利用し た操作(ソリッドを面で切断など）実行時に設計情報の 伝ぱが可能であること.

（5）決定・未決定情報の理解しやすい仕組み

設計上流といえども，概要のみ決まっている部分と 部分的には決定している場合がある．特に途中の設計

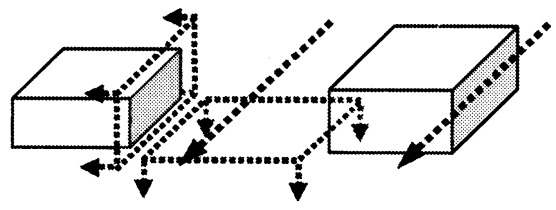

Fig. 1 Example of the Initial stage Image
工程では，混在が一般的である。これは，位置・一部 の形状などさまざまである。これらの決定・未決定な どの状況が設計者に容易に理解できる仕組みが必要で ある。

\section{3. 基本アーキテクチャの要点}

3 章では, ブレイクダウン設計支援のための前提と して, 第 1 報(7) で提案した基本アーキテクチャの要点 について簡潔に述べる。

（1）基本ア一キテクチャは，形状・寸法などの対 象に設定された設計情報・意図を正確に伝達する仕組 みを提供する，また，設計情報自身を対象として扱う ことが可能である。

（2）基本アーキテクチャは, 単独の対象に設定さ れる単体設計情報と対象間に設定される関係設計情報 を提供する。

（3）基本アーキテクチャは，各設計情報に対して, ふるまい定義体の設定を可能にする。

（4）ふるまい定義体において，対象の変化の種 類・マスプロパティ・対象幾何情報の特徵的なべクト ルなどの評価が可能である.

（5）ふるまい定義体において，上記評価結果に対 して, 設計情報の伝達方法, および操作の拒否・アラ 一ム出力などのシステムの動作を定義可能である.

上記が, 基本アーキテクチャの要点であり,これに よって, 対象に対して各設計工程で設定された設計情 報・意図が正確に伝達される仕組みを提案した。

\section{4. ブレイクダウン設計への}

\section{適用の考察と拡張}

2 章において, ブレイクダウン設計支援での重要な 5 点について述べた. 本項では，この 5 点についてさ らに考察を行い, 各項目についての提案を行う.

\section{（1） 分解機能}

段階的詳細化のためには，全体から各サブュニット に分解していく機能が必須である。

本要件は, ブレイクダウン設計そのものの支援機能 である．本機能によって個々のサブユニット・部品が 詳細化されることによって，製品全体が自動的に詳細 化される。

本要件で重要なのは, 複数のサブュニット・部品に 同時に渡るべき幾何情報が存在することである．設計 上流において，特にレイアウトを決定するうえで重要 な領域境界を表す幾何情報などである。この情報は， 複数のサブュニット・部品の詳細設計で参照すべき情 報であり，同時に複数に渡るべき情報である。 
（2）他タイプ情報の設定の必要性

非常に単純な線・平面の状態であっても, サブアセ ンブリーや部品としての設計情報・意図が設定可能で あること. 例えば, 設計上流で 1 本の線が一つの軸を 表している場合, その 1 本の線に軸として持つべき設 計情報, すなわち表面の材質, 表面粗さ, 重量制限な ど, 面あるいはモデルとしての設計情報の設定の必要 性を意味している。

これは，設計情報が現状の幾何情報種に依存せず設 定可能な仕組みが必要であることであり, 第 1 報(7) で 提案した基本ア一キテクチャで実現可能である.

（3）形状利用時の他タイプへの変更に伴う設計情 報伝ぱ

幾何形状自身の変更に伴う設計情報伝達のみなら ず, 他タイプへの変化(線を利用したソリッド化など) において, 元の幾何情報に設定されていた設計情報が, 別の新しく生成された幾何情報に伝ぱが必要なことを 表している.

これは, (2)で述べた他タイプの設計情報の設定に 伴う, 実際に幾何情報を利用した他タイプへの変化時 の設計情報の伝ぱの必要性を意味している。

本要件は, 基本アーキテクチャで述べた設計情報が 設定された幾何要素がいかなる編集を経ても設計情報 が正確に伝達される仕組み，すなわち自分自身の編集 に耐える仕組みではなく, 設計情報が設定された幾何 形状から別の新しい幾何要素へ設計情報が伝ぱする仕 組みに関する要件である。

幾何形状が具現化されるプロセスにおいて, 線が面 に, 面がソリッドに, 線がソリッドに変化していく. このプロセスにおいて, 元の幾何要素が持つモデルと しての情報(例えば重量制限など) は新しいモデルに, 元の幾何要素が持つ面としての設計情報は新しい面に 伝ぱされることが要件である.

（4）既存の幾何形状利用編集に伴う設計情報伝ぱ 設計情報の設定された幾何形状が他の幾何形状の編 集に利用された場合に, 設計情報が編集後のなんらか の幾何要素に伝ぱすべきことを表している. 本要件
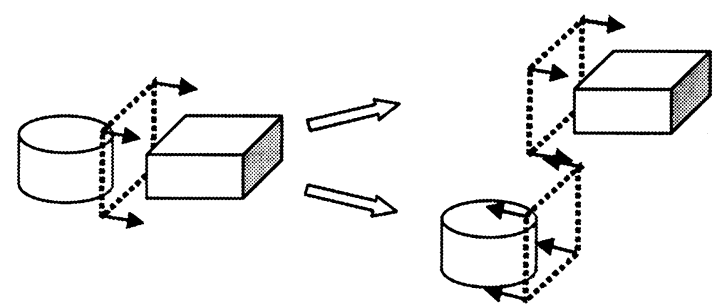

Fig. 2 Example of the model decomposition
も，基本アーキテクチャの扱う自分自身の編集に耐え る仕組みではなく，設計情報が設定された幾何形状か ら別の新しい幾何要素へ伝ぱする仕組みに関する要件 である。

例えばソリッドを面で切断する場合を想定する．面 に設定されていた精度情報が，切断面(切断されて生 成された面)に伝ぱすることである.

（5）決定・未決定情報の理解しやすい仕組み

本要件は, 基本アーキテクチャで提案したふるまい 定義体を利用することで可能である，位置関係，ある いは幾何編集に対して, ふるまい定義体を記述するこ とで, 拒否・アラーム・実行など各種の定義が可能と なることにより, 決定幾何要素の編集時の操作拒否・ アラームにより, 具体的に設計者が理解することが可 能になる。

以下に(1)，(3)，(4)についての提案を行う.

$\mathbf{4 \cdot 1}$ 分解機能 いくつかの幾何要素が存在して いる空間において，幾何要素の集合がサブアセンブリ 一として定義できることが必要である. 図 2 は, 本機 能を複数回利用して作成した例である。ここで重要な のは，このように段階的に詳細化したモデルにおいて は, 各サブアセンブリーおよび部品が詳細化されれば, 製品全体は自動的に詳細化されることである.

また, 図 2 の例において, 作業平面が複数のサブア センブリーに情報として伝ぱしているが, このように $4 \cdot 2$ 節で述べるような領域要素は, 複数のサブアセン ブリー・部品に伝ぱさせることが重要である．なぜな ら，4章(1)でも述べたように, これらの情報を遵守 して各ユニット(サブアセンブリー) 設計者が独立して 設計を進めていくうえで, 共有すべき情報であるから である。

$4 \cdot 2$ 領域境界要素 製品全体のレイアウト概要 が決まった段階の設計段階において, 重要な設計情報 の一つは配置に関する情報である. 存在領域, 特に各 サブアセンブリー・部品の領域境界を定義し, この情 報が設計下流へ伝達されることは非常に重要である.

このために, 領域境界なる設計情報を導入する，領 域境界設計情報は，モデル(サブアセンブリー・部品） が指定した幾何要素に対して, どちら側に存在すべき かを表す. 本設計情報は, 基本アーキテクチャで述べ た, モデルと幾何要素間の関係設計情報として定義さ れる.この情報の重要な点は, 全体のレイアウトを決 定する基本となる情報であり，4・1 節で述べた分解機 能により各詳細設計者に情報が渡った後, 各詳細設計 者が変更を自由に行えないことである，したがって， 例えば図 3 に示すようなふるまい定義体の利用が考え 
られる。本例は，すべての形状変更を許さない例であ る.

、図 4 は，領域境界設計情報の例である.ソリッド要 素の内部・外部，あるいは指定面からの方向付きの領 域を表している。このように，領域境界を表す幾何要 素として, ソリッド, 面群, 作業平面などが指定可能 である.

以下に領域境界の応用例を示す．なんらかの要件で 領域境界からある程度距離をあける必要がある場合を 考える．例えば，まだ距離が数値的に表現できない時 点では図 5 のように, 編集前より近づいたらアラーム を上げ，具体化されたあとでは図 6 のように, 最短距 離が 1.0 末満になったらアラームを上げるふるまい定 義体の利用がある。このように，ふるまい定義体がデ 一タになっていることにより, 設計の進捗に伴い, 容 易に有効な変更が可能である.

$4 \cdot 3$ 伝ぱ設計情報 4 章の冒頭で示した要件整 理の中の (3)と (4)に関して述べる. 伝ば情報, すな わち幾何要素に設定された設計情報が他のモデル・幾 何要素に伝ぱする場合に, 大きく 2 種類について説明 した。端的にいえば,

（a）幾何形状自身が他幾何形状への編集に利用さ れたときの設計情報伝ぱ. 4 章の (4)で述べた，既存 の幾何形状利用編集に伴う設計情報伝ぱ事象である。

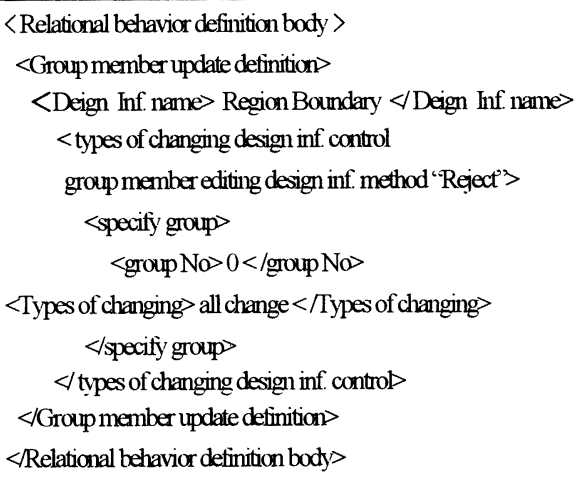

Fig. 3 Example of behavior definition for region boundaries

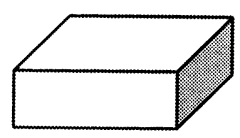

Inside of Solid

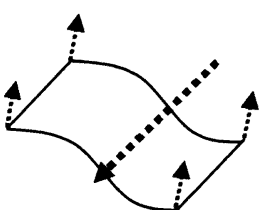

Axis: Table side of Sheet
Fig. 4 Example of region boundaries （b）幾何形状が具現化されるプロセスにおいて, 初期の幾何要素が新しい幾何情報に変化する場合の設 計情報伝ぱ. 4 章の（3)で述べた, 形状利用時の他夕 イプへの変更に伴う設計情報伝ぱである.

（a）は，切断・集合演算などの場合であり，自分自 身の幾何要素は存在しなくなるが, 同等の幾何情報が 新しく存在する場合であり, 切断・集合演算での生成 面に元の幾何形状の設計情報が伝ぱ(設定)する仕組み の構築が必要になる。

（b）は，各種の場合が想定され，以下で考察を行っ ていく.

設計上流工程においては, 個々のソリッド・面・線 が，それぞれサブアセンブリー・部品を表現している 場合が多い. したがって，個々の幾何要素にモデルと しての設計情報が設定できる必要がある.

また, 1 本の線が最終的には軸を表している場合に, 線に表面粗さなどの面に関する設計情報が設定できる 必要がある。これらの課題を整理すると下記のパター ンに整理できる。

（1）モデル自身に関する設計情報

（a）単体設計情報 幾何要素が具現化されるプ ロセスにおいても，モデル(サブアセンブリー・部品）

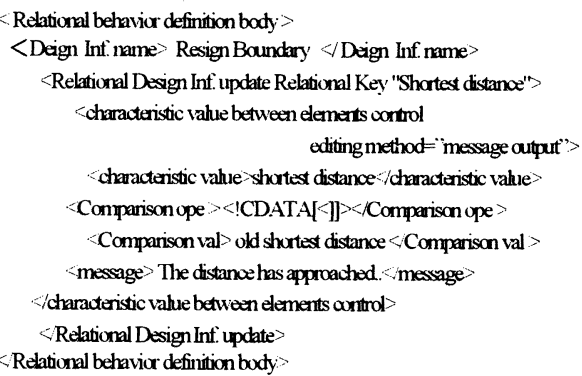

Fig. 5 Example of the behavior definition for region boundary

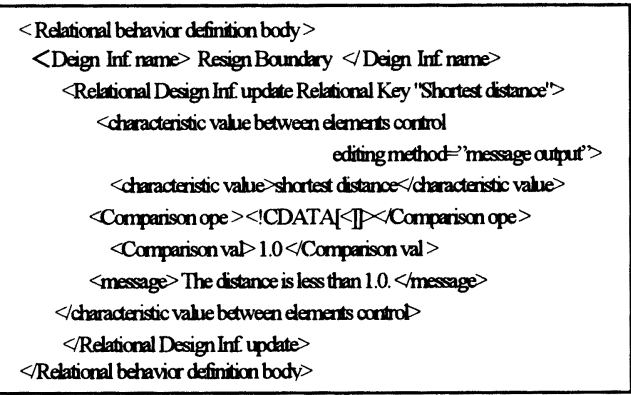

Fig. 6 Example of the behavior definition for region boundary 
に設定された設計情報として扱っていくもの. 基本ア ーキテクチャで可能である.

例えば, 重量・体積など。

（b）関係設計情報 モデルと指定幾何要素間, あるいはモデル間に設定された関係情報として扱って いくものであり，基本アーキテクチャで可能である.

例えば，領域境界設計情報など。

（2）モデルに含まれる幾何要素に関する設計情報 （a）単体設計情報面に関する精度情報など, 当初の幾何形状が具現化されていく段階で生成される 面などの幾何要素に伝ぱしていくべきもの.この場 合, 無条件にすべての生成された面に伝ぱするケース と伝ぱ対象が特定可能な場合があり, 重要なものは特 定できるように扱うことが必要である.

例えば，表面粗さなどは本例であるが，軸を表す線 に設定された表面粗さ情報は, 軸作成時に回転面に伝 ぱすべきであり, 伝ぱ対象を記述できる仕組みが重要 である.このように, 線が面に・面がソリッドになど タイプが変更される場合に, 設定された設計情報が新 しく生成される幾何データへの伝ぱ先を記述できる仕 組みの拡張が基本アーキテクチャに対して必要にな る.図 7 は, 設計情報記述において, 伝ぱ先対象を含 めて伝ば情報として定義可能とすることで実現した例 である。

（b）関係設計情報 モデル内の指定幾何要素間 の関係であり, 指定幾何要素が具現化されるプロセス において, 単なる変形は基本アーキテクチャの範ちゅ うであるが, 線が面/ソリッドなどに変化する場合に 伝ぱの考慮が必要になる。

例えば，二つの線の間に平行なる設計情報が設定さ れていた場合, その線を利用した軸物の軸間も平行で あるべきである，線を利用した回転体生成時に回転体

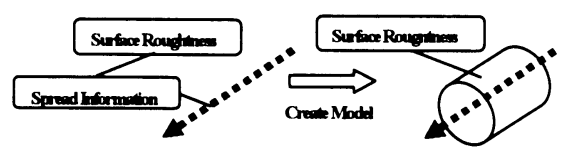

Fig. 7 Example of spread information
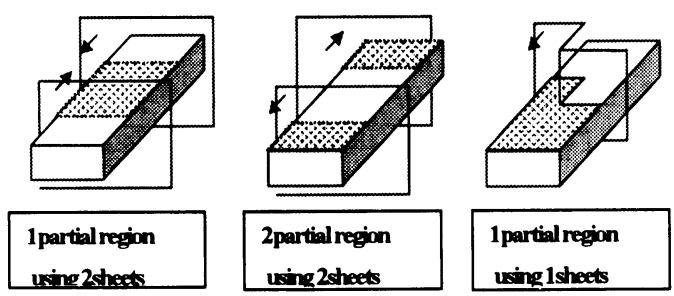

Fig. 8 Image of partial region definition
の軸を平行なる関係設計情報のグループメンバに登録 することが必要となる。

\section{5. 効果的な拡張例}

第 1 報(7)において, 基本アーキテクチャの拡張性に ついて述べたが, 要点は, 本アーキテクチャの構成要 素である, 設計情報・ふるまい定義体・対象・変化種 の構成要素の独立性である.

・対象・設計情報・ふるまい・変化種とプログラムの 独立性

・設計情報およびふるまい定義体のデータ化

5 章では, 具体的に効果的な拡張例について述べる.

$5 \cdot 1$ 部分領域とその応用いま，軸物を想定す ると, 先端部分だけ磨き上げる必要がある場合があ る.これは，面の一部のみ異なる表面粗さ情報設定す る必要があることを意味している。一方, 応力解析な どを想定した場合に，面の一部に応力をかけて解析を 行う場合がある.この場合も，面の一部の領域に設計 情報を設定する必要がある例である。

上記のように, 面の部分領域に設計情報を設定可能 にすることは, 各種の応用において有効である.

基本アーキテクチャにおける対象の独立性から, 対 象として部分領域を取扱う方式を提案することによ り, 基本アーキテクチャが持つ設計情報・ふるまい定 義体などすべての概念の適用が部分領域に対して可能 となる.

部分領域を対象として取扱うために, 部分領域の定 義方法について述べる. 部分領域をオリジナルな面お よび境界を表すためのシートグループで定義する.こ こで, シートとは連なった面群のことである. シート グループは, 複数の方向付きのシートおよび作業平面 から構成される。これらの方向付きシートグループ群 で境界付けられたオリジナルな面の領域を部分領域と 定義する.

図 8 は, 部分領域の典型的な例を表しており,一般 的に複数の領域が一つの部分領域として定義可能にな っていることを表している. 図 9 は, 部分領域のデー 夕形式イメージであり, 図 10 は, 部分領域に対して表 面粗さ情報を設定している画面例である。

$5 \cdot 2$ 設計情報の対象化と応用 前回報告(7)にお いて述べたように，設計情報自身も対象として扱うこ とが可能である.すなわち, 設計情報に新たな設計情 報を設定することが可能である.

本報では，設計情報を対象化したときの効果的な応 用例について述べる. 本提案では, 設計変更なる設計 情報を提案する. 設計変更は, 設計情報の一つであり, 
したがって全対象に対して設定可能な設計情報であ る.図11の上段に示す例は，リブフィーチャが変更 された場命に，リブフィーチャに設計情報として 設 計変更’が設定される一般的な例である。下段に示す 例は，面に ‘表面粗さ’が設計情報として設定されて おり，虫の ‘表面粗さ’なる設計情報が変更された場 合に，“設計変更”という設計情報が'表面粗さ’なる 設計情報に設定される例である。

この拡張は，機能上自然な拡張であるが，特に有効 な応閏が考えられる。

多くの企業内の設計において, 初版の設計が完了し た段階からの設計変更については，変更内答記述を義 務付けることが多い. 以降このような変更を“設変” と呼ぶととする。三次元 CADの普及に伴い, 本来 三次元 CAD で設計変更内容を詪述・保持できること が望ましいが，現状の三次元 CADではシステム支援 が筫弱でありかざわざ一度図面化を行い,コメント を図面に記述している場合も多い。非効率のみなら ず，情報のミスも考えられるのが現状である。“設変” において，提案するアーキテクチャ扔よび設計変更な る設計情報を適用することは，效果が大きい。

設計変更情報を設定することで，確実かつ継続して 情報伝達が可能になる。また，幾何情報を含めて，変 更された对象が容易に，明示的に理解寸ることが可能 になる、他の一般的な悴報の履歴保管方法(操作履歴, 形状変更履歴) は, 本提案に比較して。以下の点で課 題加残る。

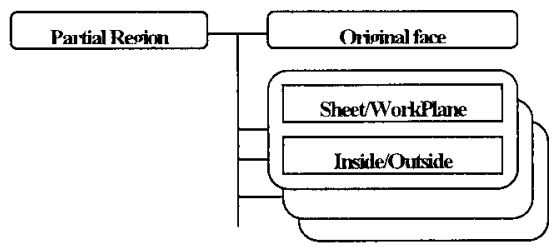

Fig. 9 Data structure image of partial region

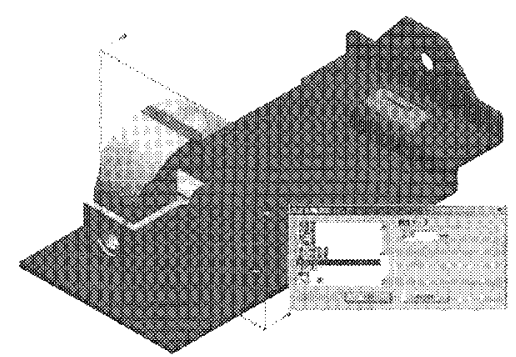

Fig. 10 Picture of setting surface roughness to partial region
・すべての履歴を順番にたどらなけ机ば理解できな w.

・最終形状内に打いて途中で変更された要素を明示す ることは非常に困難である。

本提案により，大きに二つの設計フェーズで有効に なる。

（1）“設変”時に，不当懆作の防止などが可能.

（2）“設変”肉容確認時に正確加つ直感的に理解可 能.

図 12 は，設計変更時に設計変更の意図を入力して いる例でり，図13は，“設変”内容確認のために “設変”内容一覧を出扎た画面例である.

\section{6. ブレイクダウン設計への応用}

最後に，提案した統合モデルのブレイクダウン設計 への応用を，作成した実験システムを用いて説明す る。

以下の例の中で，モデル分解・領域境界・設計情報 伝ぱについて説明する。プリン夕設計の例である。

Step 1：最初に設計䝴任者は，紙の流れを設計し，主 要なコンポーネントの眍置を検討する。形状は未確定 であり，大きさ・配置の概要を決定していくが，その 中で各コンポーネントが満たすべき領域境界や最終的 なコンポーネントに設定されるべき重要な伝ぱ設計情 報をシステムに設定していく。

Step 2：設計趩任者は，線・面・ソリッドなど領域境 界を含む幾何要素群を指示して，各コンポーネントを 作成する。これにより，第一段階めの製品の構成が決 定される。

Step 3: 各コンポーネントの設計者は, 設計を進めて いく，図14は，ドラムの口径を変更して，紙の流れを 表寸領域境界をオーバした場合である。システムがア ラームメッセージを出力している例である。

Step 4：この状態を回避するために，設計者は口径を 再度，アラームが出力されなくなるように変更を行 う.

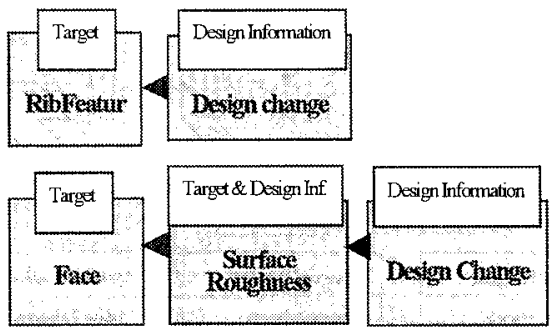

Fig. 11 Inage of design information for design change 
Step 5：コンポーネント設計者は, 軸を表す線を利用 してローラを作成する。この軸を表す線に伝ぱ設計情 報が設定されていたため, 作成されたローラには設計 情報が伝ぱする。

図 15 は，ローラの持つ設計情報の出力例であり，表 面粗さと材質が設定されている画面である。

Step 6:Step 3，4，5 繰返して設計者は設計作業を 進めていく。必要に応じて, コンポーネントは細分化 さ扎段階的に詳細化されていく。このようなブレイク ダウン設計において, 各コンポーネントの設計完了は, すな⿰ち製品全体の設計完了を意味する。

\section{7. ま と め}

本論文に扔いて，第1報において提案した基本ア一 キテクチャをべースに, 設計上流から段階的に詳細化 していくブレイクダゥン設計に执いて, 設計情報伝達 に関する重要要件について考察し，加えて基本アーキ テクチャの搪張性を論じて効果的な拡張を提案した。

まず，段階的詳細化設計支援において重要となる， 分解機能・領域境界・設計情報伝ぱを論じ, 提案を行 った，特に，設計情報伝達に関する基本アーキテクチ ヤの拡㲀の観点を以下のように整理した。

（1）自分自身の幾何要素は存在しなくなるが, 同

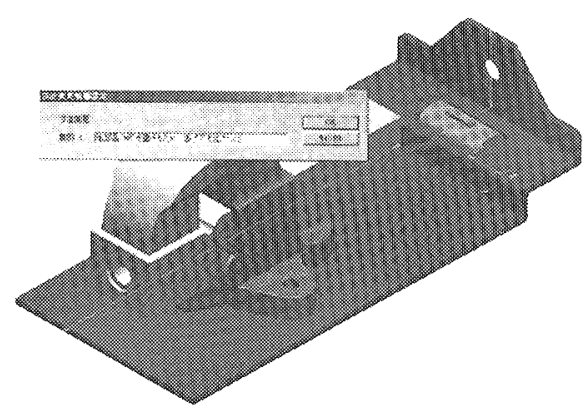

Fig. 12 Inage of design information for design change

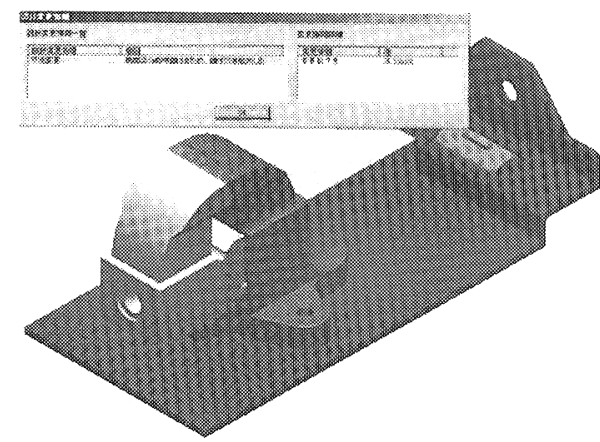

Fig. 13 Image of design information for design change
等の幾何情報が新しく存在する場合の設計情報伝ぱ (切断, 集合演算など).

（2）線が面に・面がソリッドになど簡易形状から 具現化されていくときの, 設定された設計情報が新し く生成される幾何データへの伝ぱ。

設計情報伝ぱの提案は，設計情報を伝達するうえで， 設計上流での簡易形状に設定されていた情報が，具現 化プロセスにおいても有効に伝達される仕組みである と考える。

さらに，部分領域・設計情報の刘象拡大により，具 体的な応用例を示した。基本アーキテクチャの持つ設 計情報，ふるまい定義体，対象，変化などの独立性が， 㹡張性を容易にし，具体的な忍用が可能になってい כ.

実際の設計に抗いて，設計情報・意絪を正確に下流

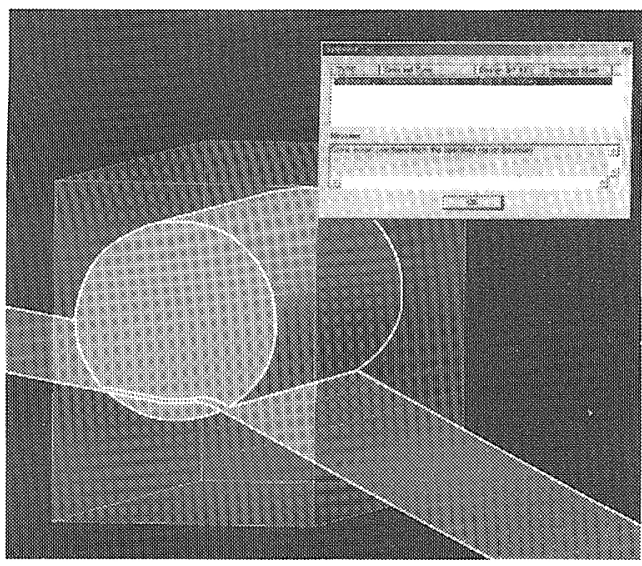

Fig. 14 Example of alarm message (over the region boundary)

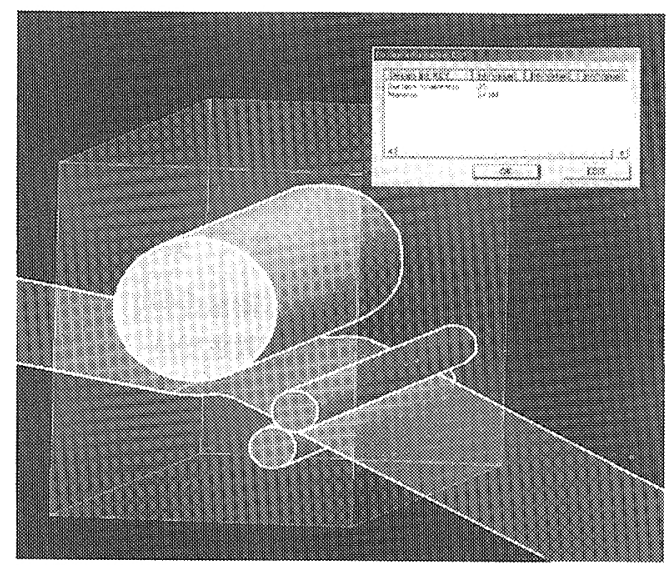

Fig. 15 Confirm the spread design information of the roller 
設計工程に伝達することは, 設計ミスの削隇, 手戻り 削減など効率化に役立つばかりでなく, 計画段階での 製品コンセプト・意図・重要要件の実現にとって非常 に重要な意味を持っている.

提案した統合モデルのアーキテクチャは, 設計の上 流から下流まで支援する拡張性に富むア一キテクチャ であり，設計情報・意図を伴った設計上流から下流ま での設計プロセス支援の一つの有効な方法論であると 考える.

\section{文献}

（1）吉川弘之・富山哲男監修，インテリジェント $\mathrm{CAD}$ (上), (1989), 朝倉書店.

（2）吉川弘之・富山哲男監修，インテリジェント $\mathrm{CAD}$ (下), (1991)，朝倉書店.
(3) Umeda, Y., Ishii, M., Yoshioka, M., Shimomura, Y. and Tomiyama, T., Supporting Conceptual Design Based on the Function- Behavior- State Modeler, Artif. Intell. Eng. Des. Analysis, Manufact., 10-4 (1996), 275288.

（4）劉継紅・荒井栄司・井越昌紀，機械の機能検証のための 定性的運動シミュレーション, 機論, 61-585, C (1995), 2159-2166.

（5）劉継紅・Amnuay，S. - 荒井栄司 - 井越昌紀, 定性的立体 モデリング(第 1 報, 定性的立体モデルとその構造化), 機 論, 62-599, C (1996), 2897-2904.

（6）岡田公治・荒井栄司，機械設計における設計意図モデル に基づくCAD, 機論, 57-544, C (1991）283-288.

(7) Arai, E., Akasaka, H., Wakamatsu, H. and Shirase, K., Description Model of Designers' Intention in CAD System and Application for Redesign Process, JSME Int. J., Ser. C, 43-1 (2000), 177-182.

（8）竹内一博・妻屋彰・若松栄史・荒井栄司, 設計情報・意 図を伴う設計プロセス支援のための統合モデル（第一報 統合モデルの基本アーキテクチャ), 機論 (C 編) 投稿中. 